\title{
Pembuatan Dan Karakterisasi Komposit Bermatriks Poliester Tak Jenuh Dengan Filler Serat Batang Pisang Riris Manihuruk dan Henok Siagian*
}

Jurusan Fisika, Fakultas Matematika dan Ilmu Pengetahuan Alam, Universitas Negeri

Medan, Indonesia

\begin{abstract}
Abstrak
Penelitian ini menitikberatkan pada pemanfaatan serat batang pisang sebagai bahan baku alternatif dalam pembuatan papan komposit. Penggunaan serat batang pisang bertujuan untuk mengetahui pengaruh variasi fraksi massa dan orientasi serat terhadap karakteristik komposit polimer. Matriks yang digunakan adalah polyester tak jenuh (Unsaturated Polyester Resin) dengan katalis Methyl Ethyl Ketone Peroxida (MEKPo) sebesar 1\% dari massa Polyester. Sampel dibuat dengan komposisi antara matriks dengan filler dengan perbandingan: (100:0), (99,5:0,5), (99:1), (98,5:1,5), dan (98:2). Karakterisasi yang dilakukan meliputi pengujian mekanik (uji lentur dan uji tarik) dan pengujian termal (uji kemampuan nyala). Hasil penelitian menunjukkan bahwa penggunaan serat batang pisang sebagai pengisi komposit polimer dapat memberikan peningkatan sifat mekanis dan termal. Dari hasil pengujian mekanik diperoleh kuat tarik tertinggi sebesar $181,64 \mathrm{kgf} / \mathrm{cm}^{2}$ pada komposisi $(98,5: 1,5) \%$ orientasi serat searah dan yang memiliki kuat lentur terbesar adalah serat searah dengan komposisi $(99,5: 0,5) \%$ yaitu sebesar $119,22 \mathrm{kgf} / \mathrm{cm}^{2}$. Sedangkan untuk kemampuan nyala, penambahan serat tidak memberikan hasil yang optimal, namun komposisi yang bernilai cukup baik yaitu $(98,5: 1,5) \%$ yaitu sebesar $0,0418 \mathrm{~mm} /$ detik. Secara keseluruhan serat dengan orientasi searah adalah pengisi yang memberikan pengaruh positif pada sifat mekanis dan termal komposit. Fraksi massa yang memberikan nilai optimal secara keseluruhan pengujian adalah komposisi $(98,5: 1,5) \%$
\end{abstract}

Kata Kunci ; Komposit bermatriks Poliester, serat batang pisang, kuat tarik, kuat lentur,dan kemampuan nyala.

How to Cite: Riris Manihuruk dan Henok Siagian, (2015), Pembuatan Dan Karakterisasi Komposit Bermatriks Poliester Tak Jenuh Dengan Filler Serat Batang Pisang, Jurnal Einsten Prodi Fisika FMIPA Unimed, 3 (2): 23-30.

*Corresponding author:

p-ISSN : I2338 - 1981

E-mail : ririsyanadevi@ymail.com 


\section{PENDAHULUAN}

Teknologi komposit merupakan teknologi hijau dengan menggunakan material serat alam (Natural Fiber). Komposit diartikan sebagai kombinasi antara dua material atau lebih yang berbeda bentuknya, Komposisi kimianya dan tidak saling melarutkan antara materialnya dimana material yang satu berfungsi sebagai penguat dan material yang lainnya berfungsi sebagai pengikat untuk menjaga kesatuan unsur-unsurnya (Sriwita, D. dan Astuti., 2014)

Komposit berpenguat serat banyak diaplikasikan pada alat- alat yang membutuhkan perpaduan dua sifat dasar yaitu kuat namun juga ringan. Bahan komposit memiliki banyak keungulan, diantaranya berat jenisnya rendah kekuatan yang lebih tinggi, tahan korosi dan memiliki biaya perakitan yang lebih murah. Komposit diartikan sebagai kombinasi antara dua material atau lebih yang berbeda bentuknya, Komposisi kimianya dan tidak saling melarutkan antara materialnya dimana material yang satu berfungsi sebagai penguat dan material yang lainnya berfungsi sebagai pengikat untuk menjaga kesatuan unsur-unsurnya.

Komposit berpenguat serat banyak diaplikasikan pada alat- alat yang membutuhkan perpaduan dua sifat dasar yaitu kuat namun juga ringan. Bahan komposit memiliki banyak keungulan, diantaranya berat jenisnya rendah kekuatan yang lebih tinggi, tahan korosi dan memiliki biaya perakitan yang lebih murah. Unsur utama penyusun komposit yaitu pengisi (filler) yang berupa serat sebagai kerangka dan unsur pendukung lainnya yaitu matriks. Pengisi (filler) dan matriks merupakan dua unsur yang diperlukan dalam pembentukan material komposit.

Batang pisang merupakan limbah dari tanaman pisang yang telah ditebang untuk diambil buahnya dan merupakan limbah pertanian potensil yang belum banyak pemanfaatannya. Beberapa penelitian telah mencoba untuk memanfaatkannya antara lain untuk papan partikel dan papan serat (Rahman, 2006). Ketersediaan bahan baku kayu di alam mulai berkurang, maka tidak menutup kemungkinan dikembangkan produk papan komposit dari limbah pertanian (agrobasedcomposite) dengan kualitas yang sama dengan bahan baku kayu. Limbah batang pisang merupakan salah satu alternatif bahan baku yang murah dan mudah diperoleh (Anonim, 2001). Pemberian perlakuan alkali pada bahan berlignin selulosa mampu mengubah struktur kimia dan fisik permukaan serat. Jenis matriks yang digunakan dalam penelitian ini adalah resin Unsaturated Polyester Resin (UPR).

Resin polyester merupakan salah satu resin termoset yang mudah diperoleh, selain harganya murah resin polyester ini juga mempunyai kemampuan berikatan dengan serat alam tanpa menimbulkan reaksi dan gas, tahan terhadap asam, daya tahan terhadap impak, dan pembuatannya relative mudah. Hal yang mempengaruhi ikatan antara serat dan matrik adalah void, yaitu adanya celah pada serat atau bentuk serat yang kurang sempurna yang dapat menyebabkan matrik tidak akan mampu mengisi ruang kosong pada cetakan. Bila komposit tersebut menerima beban, maka daerah tegangan akan berpindah ke daerah void sehingga akan mengurangi kekuatan komposit tersebut. Pada pengujian tarik komposit akan berakibat lolosnya serat dari matrik. Hal ini disebabkan karena kekuatan atau ikatan interfacial antara matrik dan serat yang kurang besar (Schwart, 1984)

Kayu memiliki tiga karakteristik penting : (a) Mempunyai rasio kekuatan terhadap berat yang tinggi; (b) banyak dari antara sifatnya yang anisotropic; dan (c) mudah diproses sesuai ukuran yang diinginkan (Vlack, 1995). Sehingga papan komposit yang akan menggantikan peranan kayu ini nantinya haruslah memiliki sifat seperti itu. Adapun produk akhir dari penelitian ini adalah teknologi komposit di bidang papan komposit dengan matriks polimer. Standard Nasional Indonesia (SNI) yang mengulas mengenai standar papan serat/papan komposit adalah SNI 032105-2006.

Berdasarkan kebutuhannya, maka papan komposit yang telah dibuat akan 
diberikan pengujian sifat mekanik dan sifat termal. Sifat mekanik meliputi kekuatan tarik dan kekuatan lentur, dan sifat termal meliputi kemampuan nyala bahan. Kekuatan tarik adalah salah satu sifat dasar dari bahan. Hubungan tegangan-regangan pada tarikan memberikan nilai yang cukup berubah tergantung pada laju tegangan, temperatur, lembaban, dan seterusnya. Kekuatan tarik diukur dengan menarik sekeping sampel dengan dimensi yang seragam.

Kemampuan maksimum bahan dalam menahan beban disebut "Ultimate Tensile Strength" disingkat dengan UTS. Untuk semua bahan, pada tahap sangat awal uji tarik, hubungan antara beban atau gaya yang diberikan berbanding lurus dengan perubahan panjang bahan tersebut. Ini disebut daerah linier atau linear zone. Di daerah ini, kurva pertambahan panjang vs beban mengikuti aturan Hooke, yaitu rasio tegangan (stress) dan regangan (strain) adalah konstan.

Pengujian kekuatan lentur (UFS) dimaksudkan untuk mengetahui ketahanan polimer terhadap pembebanan. Dalam metode ini metode yang digunakan adalah metode tiga titik lentur yang ditentukan dalam ASTM D 790. Pengujian ini juga dimaksudkan untuk mengetahui keelastisan suatu bahan (Schwart, 1984).

Sedangkan untuk kemampuan nyala, bahan polimer termasuk yang sangat mudah menyala seperti seluloid dan yang dapat habis terbakar sendiri secara spontan walau api dipadamkan setelah penyalaan, seperti pada polikarbonat. Sifat mampu nyala bahan polimer dapat ditentukan Dengan membakar bahan yang diletakkan mendatar .

Cara ini ditetapkan dalam JIS-K69111970 dan ASTM-D635-1974. Nyala api dari alat pembakar bunsen dipegang pada sudut $30^{\circ}$, menyalakan spesimen yang diletakkan mendatar untuk waktu selama 30 detik, dan api dijauhkan. Waktu yang diperlukan agar specimen menyala disebut waktu penyalaan dan panjang specimen yang terbakar disebut jarak bakar. Harga-harga tersebut dipakai untuk menyatakan kemampuan nyala dari bahan.

1. Mampu nyala: terbakar lebih lama dari 180 detik dengan nyala.
2. Habis terbakar sendiri: jarak bakar lebih dari $25 \mathrm{~mm}$ tetapi kurang dari $100 \mathrm{~mm}$

3. Tak mampu nyala: jarak bakar kurang dari $25 \mathrm{~mm}$.

Dalam ASTM, laju bakar menyatakan jarak bakar persatuan waktu, yang dipakai sebagai kemampuan nyala (Surdia, 2000).

\section{METODE PENELITIAN}

Penelitian untuk pembuatan dan karakterisasi komposit polyester dengan serat batang pisang ini dilakukan di Laboratorium Kimia Polimer (Pembuatan komposit) dan Laboratorium Teknik Mesin (Karakterisasi komposit) Universitas Sumatera Utara. Penelitian ini dilaksakan mulai bulan Januari - Maret 2015. Alat yang dugunakan adalah cetakan, Hot Press, neraca analitik, jangka sorong, gelas beker, pengaduk, dekortikator dan Universal Testing Machine. Bahan yang digunakan yakni, Matriks Polyester dalam bentuk cair seri Yukalac 157 BQTN-EX, katalis MEKPo, Aseton, akuades, $\mathrm{NaOH}$ $5 \%$ dan serat batng pisang.

Sampel dibentuk sesuai dengan ketentuan yang terdapat pada ASTM D 638 (Uji tarik), ASTM D 790 (Uji lentur), dan ASTM D-635 (Uji keampuan nyala). Variasi komposisi perbandingan antar poliester dengan serat batang pisang yang digunakan dalam penelitian ini adalah (100:0)\%, $\quad(99,5: 0,5) \%, \quad(99: 1) \%$, $(98,5: 1,5) \%$ dan $(98: 2) \%$.

Metode yang digunakan pada penelitian ini adalah kajian eksperimental. Secara umum urutan tahapan penelitian ini meliputi :

1. Penyediaan alat dan bahan

2. Pembuatan Filler (Dekortikasi, perendaman dengan $\mathrm{NaOH} 5 \%$, dan pengeringan)

3. Pembuatan matriks (Resin Poliester + katalis MEKPo(1\% massa resin)

4. Mixing (Matrik + Filler)

5. Pencetakan (dengan variasi serat acak dan searah untuk setiap komposisi)

6. Pendinginan

7. Pembentukan bahan uji

8. Pengkarakterisasian komposit 
kekuatan tarik minimum yang direkomendasikan untuk jenis papan biasa

\begin{tabular}{|c|c|c|c|c|c|c|}
\hline $\begin{array}{l}\text { Orient } \\
\text { asi }\end{array}$ & \begin{tabular}{|l|} 
No. \\
Sampe \\
1
\end{tabular} & $\begin{array}{l}\text { Komposi } \\
\text { si } \\
\text { Sampel }\end{array}$ & $\begin{array}{l}P_{\text {maks }} \\
\text { (kgf) }\end{array}$ & $\begin{array}{l}\text { Kuat } \\
\text { Tarik } \\
\left(\mathrm{kgf} / \mathrm{cm}^{2}\right)\end{array}$ & \begin{tabular}{|l} 
Elongat \\
ion \\
$(\%)$
\end{tabular} & \begin{tabular}{|l} 
MOE \\
(MPa)
\end{tabular} \\
\hline & 1 & \begin{tabular}{|l|}
$100: 0$ \\
\end{tabular} & 8,962 & 54,95 & 2,73 & 310,499 \\
\hline$\overline{\mathrm{A}}$ & 2 & $99,5: 0,5$ & 20,751 & 172,7 & 4,25 & 260,157 \\
\hline C & 3 & 99:1 & 24,637 & 175,27 & 4,37 & 279,184 \\
\hline A & 4 & $98,5: 1,5$ & 18,524 & 176,3 & 4,4 & 243,160 \\
\hline $\mathrm{K}$ & 5 & $98: 2$ & 29,293 & 180,24 & 4,4 & 349,814 \\
\hline \multirow{4}{*}{$\begin{array}{l}\text { S } \\
\text { E } \\
\text { A } \\
\text { R } \\
\text { A } \\
\text { H }\end{array}$} & 6 & 99,5:0,5 & 25,793 & 180,3 & 4,4 & 332,129 \\
\hline & 7 & 99:1 & 30,015 & 181,64 & 4,78 & 350,735 \\
\hline & 8 & $98,5: 1,5$ & 29,321 & 182,1 & 4,83 & 349,462 \\
\hline & 9 & 98:2 & 27,939 & 171,14 & 5,00 & 287,897 \\
\hline
\end{tabular}

\section{Pengujian Kuat Tarik}

Sampel yang telah dicetak sesuai dengan ukurannya diletakkan pada kedua penjepit (grid) yang posisinya tegak lurus pada alat tarik. Saklar mesin tarik dan saklar pencatat grafik dihidupkan bersama-sama dimana kecepatan tarik mesin. Dari hasil pengujian mesin uji akan diperoleh hubunga antara gaa tarik tehadap pertambahan panjang.

\section{Pengujian Kuat Lentur}

Sampel yang telah dicetak, diletakkan pada kedua titik penahan dengan jarak span 120 mm. Pembebanan dilakukan pada tiga titik lentur. Hasil pengujian berupa grafik hubungan antara kakas (gaya) tekan terhadap defleksi diperoleh dari mesin uji.

\section{Pengujian Kemampuan Nyala}

Hasil pengujian berupa ketahanan nyala komposit diolah berdasarkan waktu penyalaan (detik) dan panjang spesimen yang terbakar (mm). sehungga satuan akhir ketahanan nyala yang diperoleh adalah $\mathrm{mm} /$ detik.

\section{HASIL DAN PEMBAHASAN Hasil Pengujian Kuat Tarik}

Dari pengujian kekuatan tarik diketahui hubungan tegangan dan regangan yang dapat diterima oleh papan komposit. Hal ini berhubungan dengan tegangan maksimum yang bisa di tahan struktur pada kondisi tarik. Berdasarkan acuan yang digunakan yaitu SNI 03-2105-2006,

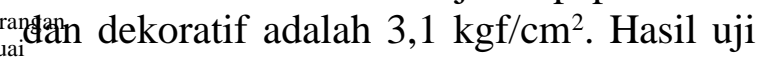
Acuantarik komposit polimer bermatriks Poliester Memenuffengan filler serat batang pisang, Memenudititunjukkan pada tabel dibawah ini. Memenuhi

Memenuhi Tabel 1. Hasil Pengujian Kekuatan Memenuhi Tarik

\section{Kuat Lentur}

Dari Pengujian Kekuatan Lentur emendiketahui ketahanan polimer terhadap pembebanan. Dalam metode yang digunakan adalah metode tiga titik lentur berdasarkan standar pengujian yang ditentukan oleh ASTM D 790. Berikut hasil Pengujian Kuat Lentur Komposit bermatriks Polyester dengan filler serat batang pisang.

Berdasarkan acuan SNI 03-2105-2006 kuat lentur minimum dan modulus elastisitas untuk jenis papan biasa dan dekoratif yang direkomendasikan berturut-turut adalah 92 $\mathrm{kgf} / \mathrm{cm}^{2}$ dan $3,06 \times 10^{4} \mathrm{kgf} / \mathrm{cm}^{2}$.

Tabel 2. Hasil pengujian Kuat Lentur

\begin{tabular}{|c|c|c|c|c|c|c|}
\hline $\begin{array}{c}\text { No. } \\
\text { Samp } \\
\text { el }\end{array}$ & $\begin{array}{c}\text { Komposisi } \\
\text { Sampel }\end{array}$ & $\begin{array}{c}\mathrm{P}_{\text {maks }} \\
(\mathrm{N})\end{array}$ & $\begin{array}{c}\text { Defleksi } \\
(\mathrm{mm})\end{array}$ & $\begin{array}{c}\text { Kuat Lentur } \\
\left(\mathrm{kgf} / \mathrm{cm}^{2}\right)\end{array}$ & $\begin{array}{c}\text { Modulus } \\
\text { Elastisitas } \\
\left(10^{4}\right. \\
\left.\mathrm{kgf} / \mathrm{cm}^{2}\right)\end{array}$ & $\begin{array}{c}\text { Keterangan } \\
\text { (Sesuai } \\
\text { Acuan })\end{array}$ \\
\hline 1 & $100: 0$ & 17,6 & 1,83 & 86,84 & 4,27 & $\mathrm{TM}$ \\
\hline 2 & $99,5: 0,5$ & 18,2 & 1,96 & 117,29 & 6,15 & Memenuhi \\
\hline 4 & $99: 1$ & 17 & 1,89 & 109,55 & 5,96 & Memenuhi \\
\hline 5 & $98: 2$ & 18,7 & 2,05 & 120,51 & 6,05 & Memenuhi \\
\hline 7 & $99,5: 0,5$ & 18,5 & 1,93 & 119,22 & 6,35 & Memenuhi \\
9 & $98: 2$ & 18,7 & 1,97 & 92,267 & 4,215 & Memenuhi \\
\hline
\end{tabular}

\section{Kemampuan Nyala}

Bahan polimer merupakan material yang sangat mudah menyala dan dapat habis terbakar sendiri. Berikut merupakan hasil pengujian ketahanan nyala komposit polimer dengan filler serat batang pisang 
Tabel 3. Hasil Pengujian Ketahanan Nyala

\begin{tabular}{|c|c|c|c|}
\hline $\begin{array}{c}\text { Orientasi } \\
\text { Serat }\end{array}$ & $\begin{array}{c}\text { Nomor } \\
\text { Sampel }\end{array}$ & $\begin{array}{c}\text { Komposisi } \\
\text { Sampel (\%) }\end{array}$ & $\begin{array}{c}\text { Kemampuan } \\
\text { Nyala (mm/s) }\end{array}$ \\
\hline & 1 & $100: 0$ & 0,0508 \\
A & 2 & $99,5: 0,5$ & 0,0692 \\
C & 3 & $99: 1$ & 0,0601 \\
A & 4 & $98,5: 1,5$ & 0,0582 \\
K & 5 & $98: 2$ & 0,0564 \\
\hline S & 6 & $99,5: 1,5$ & 0,0529 \\
E & 7 & $99: 1$ & 0,0536 \\
A & 8 & $98,5: 1,5$ & 0,0418 \\
R & 9 & $98: 2$ & 0,0507 \\
A & 9 & & \\
H & &
\end{tabular}

\section{Pembahasan Kuat Tarik}

Berdasarkan data hasil pengujian pada tabel 1, dapat diperoleh hubungan antara fraksi massa serat dan orientasi serat dengan kuat tarik (Tensile Strength), regangan (elongation), dan modulus elastisitas (Modulus of Elasticity) dengan penggambaran melalui grafik. Berikut disajikan hubungan kuat tarik dengan massa serat acak dan searah.

Grafik 1. Hubungan kuat tarik dengan massa serat acak dan searah

Berdasarkan grafik, dapat diketahui bahwa tegangan maksimum terbesar yang dapat diterima bahan yaitu sebesar 181,64 $\mathrm{kgf} / \mathrm{cm}^{2}$ pada komposisi serat $1,5 \%$ dengan orientasi serat searah. Sedangkan untuk kuat tarik maksimum terendah terdapat pada polyester tanpa penambahan filler (serat batang pisang) yaitu $54,95 \mathrm{kgf} / \mathrm{cm}^{2}$. Nilai kuat tarik tertinggi yang dihasilkan relatif lebih besar dari nilai kuat tarik serat nenas-poliester memiliki nilai kekuatan tarik sebesar 5,12 Mpa atau sama dengan $52,19 \mathrm{kgf} / \mathrm{cm}^{2}$ merupakan hasil dari penelitian (Delni Sriwita, Astuti, 2014), dan kuat tarik serbuk serat batang pisang dengan matriks $\mathrm{PVC}-\mathrm{CaCO}_{3}$ yang merupakan hasil penelitian (Supraptiningsih,2012) dengan hasil kuat tarik tertinggi sebesar 7,93 $\mathrm{MPa}$ atau sama dengan $80,80 \mathrm{kgf} / \mathrm{cm}^{2}$.

\section{Kuat Lentur}

Pengujian kekuatan lentur yang disajikan pada table 2 membuktikan keberadaan serat dapat menambah kekuatan lentur material komposit. Tetapi variasi fraksi massa ini tidak memberikan perkembangan yang stabil pada papan komposit. Hal ini memberikan pengertian bahwa komposit polimer yang dibuat dengan penambahan serat batang pisang sebagai penguat harus lebih diutamakan pada percobaan komposisi terlebih dahulu. Untuk lebih jelasnya dapat dilihat dari grafik yang disajikan berikut

\section{Grafik 2. Hubungan Kuat Lentur dengan massa serat acak dan searah}

Berdasarkan grafik 2 hasil pengujian beban lentur komposit polimer memperlihatkan bahwa kuat lentur tertinggi pada serat dengan orientasi acak adalah pada massa serat $2 \%$ yaitu sebesar $120,51 \mathrm{kgf} / \mathrm{cm}^{2}$. Dan kuat lentur terendah pada polyester murni (tanpa penambahan serat) yaitu sebesar 86,84 $\mathrm{kgf} / \mathrm{cm}^{2}$. Grafik menunjukkan bahwa penambahan massa serat memberikan perubahan kuat lentur yang tidak stabil.

Pada orientasi serat searah, kuat lentur tertinggi yang diperoleh pada komposisi massa serat $2 \%$ adalah yang tertinggi yaitu sebesar $124,3 \mathrm{kgf} / \mathrm{cm}^{2}$. Dan yang terendah pada komposisi massa serat $1 \%$ yaitu sebesar 92,267 $\mathrm{kgf} / \mathrm{cm}^{2}$.

Secara kolektif, nilai kuat lentur yang terbaik diperoleh dengan orientasi serat searah. Walaupun tidak memberikan peningkatan kuat lentur yang signifikan, kuat lentur dengan 
orientasi serat searah memiliki nilai lebih tinggi dibandingkan dengan serat orientasi acak. Nilai kuat lentur tertinggi yang dihasilkan lebih tinggi dari nilai kuat lentur serat pendek sabut kelapa memiliki nilai kekuatan lentur sebesar 8,96 Mpa atau sama dengan $91,3 \mathrm{kgf} / \mathrm{cm}^{2}$ merupakan hasil dari penelitian (Erna Yusnianti, 2013), serat daun nenas memiliki kuat lentur sebesar $10,51 \mathrm{MPa}$ atau sama dengan 107,01 kgf/ $\mathrm{cm}^{2}$ (Neni Astuti, 2012).

\section{Kemampuan Nyala}

Berdasarkan pengertiannya, semakin rendah kemampuan nyala suatu bahan, maka akan semakin baik penggunaannya. Hal ini dikarenakan semakin banyaknya kebutuhan yang mengedepankan sifat anti api.

Grafik 3. Hubungan kemampuan nyala dengan massa serat acak dan searah

Pengujian kemampuan nyala ini ditujukan untuk mengetahui pengembangan serat-serat yang tak dapat nyala untuk kemajuan fungsi komposit tahan api. Berdasarkan grafik diatas, kemampuan nyala terendah diperoleh pada komposisi serat 1,5\% dengan orientasi serat searah yaitu 0,0418 $\mathrm{mm} / \mathrm{s}$. Ini merupakan nilai terbaik karena semakin rendah kemampuan nyala bahan, maka semakin baik ketahanannya terhadap api. Sementara itu, bahan dengan kemampuan nyala tertinggi diperoleh pada komposisi serat $0,5 \%$ yaitu sebesar $0.0692 \mathrm{~mm} / \mathrm{s}$.

\section{KESIMPULAN DAN SARAN}

Berdasarkan hasil penelitian mekanik dan termal yang telah dilakukan pada komposit polimer matriks Polyester dengan filler serat batang pisang, maka diperoleh kesimpulan sebagai berikut :

1. Secara umum, sifat mekanik (uji tarik dan uji lentur) yang diperoleh dari penambahan serat batang pisang meningkat dibandingkan dengan polyester tanpa penambahan serat (murni). Dan syarat mekanisnya memenuhi acuan yaitu SNI 03-21052006 dengan jenis papan biasa dan papan dekoratif. Jika dilihat dari sifat termalnya, komposit polyesterserat batang pisang memiliki nilai yang kurang baik, karena polyester mengandung monomer yang memperbanyak oksigen ketika komposit menerima perlakuan panas.

2. Fraksi massa serat batang pisang cukup berpengaruh dalam menaikkan sifat mekanis komposit polimer. Untuk sifat mekanik, komposisi sampel yang memiliki kuat tarik terbesar adalah $(98,5$ : $1,5) \%$ yaitu sebesar $181,64 \mathrm{kgf} / \mathrm{cm}^{2}$ dan yang memiliki kuat lentur terbesar adalah $(99,5: 0,5) \%$ yaitu sebesar 119,22 $\mathrm{kgf} / \mathrm{cm}^{2}$. Sedangkan untuk ketahanan nyala, penambahan serat tidak memberikan hasil yang optimal, namun komposisi yang bernilai cukup baik yaitu $(98,5: 1,5) \%$ yaitu sebesar 0,0418 $\mathrm{mm} /$ detik.

3. Berdasarkan orientasinya, serat dengan orientasi searah memiliki pengaruh besar pada pengujian tarik dan pengujian kemampuan nyala, dan serat dengan orientasi acak memiliki nilai yang baik pada pengujian kuat lentur.

\section{SARAN}

Untuk penelitian selanjutnya diharapkan :

1. Untuk mendapatkan komposit polimer yang optimal, sebaiknya fraksi massa maupun orientasi serat dibuat dengan teliti dan pencampuran (mixing) yang baik.

2. Untuk mendapatkan komposit polimer yang lebih elastis perlu penggunaan serat lain yang memiliki nilai kuat lentur yang lebih tinggi.

3. Jika akan melakukan pengujian ketahanan nyala 
selanjutnya, sebaiknya menggunakan bahan yang mengandung gugus arang yang baik (polimer aromatik) ataupun dengan menginovasi cara untuk ketahanan nyala yang optimal sesuai output yang diharapkan.

\section{DAFTAR PUSTAKA}

Anonim.,( 2001), Technical Data Sheet, Justus Kimia Raya.

ASTM D-638, ASTM D-790, dan ASTM

D-635., (1990), Standard and Literature References for Composite Materials, $2^{\text {nd }}$, American Society for Testing Material, Philadelphia, PA.

Rahman, H., (2006), Pembuatan Pulp dari Batang Pisang Uter (Musa Paradisiaca Linn. Var uter) Pascapanen dengan Proses Soda., Skripsi, Fakultas Kehutanan, UGM, Yogyakarta.

Schwart, M.M., (1984), Composite Material Handbook, Mc Graw-Hill Book Co., New York

Sriwita, D. dan Astuti., (2014), Pembuatan dan Karakterisasi Sifat Mekanik Bahan Komposit Serat Daun Nenas-Poliester ditinjau dari Fraksi Massa dan Orientasi Serat, Vol.3, No.1, Januari 2014, ISSN 2302-8491.

Surdia, T., (2000), Pengetahuan Bahan Teknik, Penerbit Pradnya Paramita, Jakarta.

Vlack, L.H., (1995), Ilmu dan Teknologi Bahan, Terjemahan Ir. Sriati Djaprie, Erlangga, Jakarta. 